\title{
Freedom and Power of European Constitutional Scholarship
}

\author{
Jan Komárek*
}

What is it that European constitutional scholars are, and should be, pursuing?

The noble answer would be: knowledge, as all scholars do. However, they do much more, undoubtedly because of the nature of their discipline. Lawyers have always been close to power. ${ }^{1}$ This has consequences for the way they conduct their research and teaching and, as I argue in this article, also for their responsibility and the way in which they can combine their academic work with lawyering, business, and public advocacy. ${ }^{2}$

The article is structured as follows: I first discuss how academics' engagement with 'real-life issues' may relate to different forms of power: one governmental, or public, and the other economic, or private. The second section seeks to theorise the power which constitutional scholars exercise and show how it depends on their membership in the scientific community. The latter has, however, faced the 'crisis of scientific authority', as the following third section shows. Constitutional scholars

*Professor of European law, iCourts, Faculty of Law, University of Copenhagen. The article was written as part of the Project IMAGINE, which has received funding from the European Research Council (ERC) under the European Union's Horizon 2020 research and innovation programme (grant agreement No. 803163). More information on IMAGINE can be found at (www. imagine-const.eu , visited 4 October 2021. I would like to thank to all my colleagues who have commented on earlier drafts of this article, especially those who have encouraged me to publish it.

${ }^{1}$ See Y. Dezelay and B.G. Garth, 'Lawyers and the transformations of the fields of state power: osmosis, hysteresis and aggiornamento', in M.R. Madsen and C. Thornhill (eds), Law and the Formation of Modern Europe: Perspectives from the Historical Sociology of Law (Cambridge University Press 2014) p. 275.

${ }^{2}$ For similar recent reflections see L. Lazarus, 'Constitutional Scholars as Constitutional Actors', 48 Federal Law Review (2020) p. 483 and M. Tushnet, 'Writing While Quarantined: A Personal Interpretation of Contemporary Comparative Constitutional Law', 15 ICL Journal (2021) p. 53.

European Constitutional Law Review, 17: 422-441, 2021

(C) The Author(s), 2021. Published by Cambridge University Press on behalf of European Constitutional Law Review. This is an Open Access article, distributed under the terms of the Creative Commons Attribution licence (http://creativecommons.org/licenses/by/4.0/), which permits unrestricted re-use, distribution, and reproduction in any medium, provided the original work is properly cited. doi:10.1017/S157401962100033X 
have not been immune to pressures that academics in all fields have been facing, and the fourth section therefore deals with academic freedom - the notion derived not only from the post-war catalogues of fundamental rights, but something that goes deeper to the 'history of the university' and its place in the society. Freedom, however, also means responsibility and in my view, academic freedom requires restraint on the part of individual academics, if we want to preserve it for all - the academic collective and all its individual members (see the fifth section). The power of the academic collective is looked at critically in the final section of this article: a call for critical judgment and resistance to group thinking.

\section{CONSTITUTIONAL SCHOLARS AND POWER}

Constitutional law is closely linked to politics. Being a constitutional scholar has always meant at least touching on the latter - no matter how much one might try to avoid this predicament. It has also meant exercising a form of power. ${ }^{3}$ The moment a constitutional scholar expresses her opinion on a constitutional controversy, which is also a political controversy due to the structural coupling between constitutional law and politics, ${ }^{4}$ she contributes to how the controversy is going to be approached (and possibly even solved). This is true at least in countries where acting in compliance with the constitution is important. Constitutional scholarship may not be the same as politics and power, but it is certainly difficult to separate them. This relates to what Kaarlo Tuori calls the 'imposed normativity of all legal scholarship. ${ }^{5}$ Normativity (and power) is 'imposed' because it can never be fully escaped by legal scholars.

Some scholars embrace this fact and frequently engage in politics - or 'public debate', if it makes sense to deem the latter as something different from politics. Their efforts are further supported by calls to 'step outside the Ivory Tower' and make their work relevant for society. ${ }^{6}$ Social impact and scholars' outreach to the general public have become important elements of the evaluation of academic work by public and private funders. Wojciech Sadurski, the author of the book

\footnotetext{
${ }^{3}$ As this piece essentially offers a reflection on a number of contemporary issues (albeit, and hopefully, in a theoretically informed way), it does not offer a comprehensive theory of academic scholarship's power. Were this tried at some point, this piece would be fundamental: R. Forst (C. Cronin transl), Normativity and Power: Analyzing Social Orders of Justification (Oxford University Press 2017) Ch. 2 on 'Noumenal Power'.

${ }^{4}$ For an incisive analysis of this phenomenon based on Niklas Luhmann's system theory see K. Tuori, Ratio and Voluntas: The Tension between Reason and Will in Law (Ashgate 2011) Ch. 7 on the 'Rule of Law and Rechtstaat'; specifically on 'structural coupling' p. 208.

${ }^{5}$ Tuori, supra n. 4, p. xiii and p. 11-16.

${ }^{6}$ See S Collini, What Are Universities For? (Penguin 2012).
} 
titled Poland's Constitutional Breakdown, ${ }^{7}$ is surely one of the most prominent examples in today's Europe. He asked recently why would "'joining a prorule-of-law political party" or "holding speeches in pro-rule-of-law demonstrations" ... contaminate the integrity of a scholar?' 'Sure, all analogies may be misleading, but isn't it a little like an epidemiologist who actively participates in public actions to counter the pandemic, as long as the view she propounds in public meetings are sincerely held and based on her scientific knowledge?'?

Sadurski speaks from his own experience: apart from writing academic publications he is very active in the public sphere, including social media. After he called the ruling Law and Justice Party an 'organised criminal group' on Twitter, the party brought a civil lawsuit against him, seeking apology and compensation of 20,000 złoty (approximately $€ 4,500$ ). ${ }^{10}$ Sadurski was also sued by Telewizja Polska, a TV station fully controlled by PiS, both for civil and criminal defamation, following a tweet in which he described it as a 'Goebbelsian media company. ${ }^{11}$

Two colleagues of Sadurski wrote an open letter in his support, and invited fellow academics to co-sign the letter. ${ }^{12}$ On Verfassungsblog alone it has received over 700 statements of support. ${ }^{13}$ We cannot know with certainty whether such massive support (further reinforced by concrete steps taken within EU institutions) has had any influence on the outcome of these disputes (some of them still pending). ${ }^{14}$ However, the scholars involved in the campaign to support Wojciech

${ }^{7}$ W. Sadurski, Poland's Constitutional Breakdown (Oxford University Press 2019).

${ }^{8} \mathrm{~W}$. Sadurski, 'Are These 'Moral Dilemmas' Real? A Response to András Jakab', Verfassungsblog, 16 July 2020, 〈https://verfassungsblog.de/are-these-moral-dilemmas-real/〉, visited 4 October 2021.

${ }^{9}$ Ibid.

${ }^{10}$ See 'PiS pozywa znanego profesora. Za 'zorganizowaną grupe przestępczą", Do Rzeczy, 29 January 2019, 〈https://dorzeczy.pl/kraj/91714/PiS-pozywa-znanego-profesora-Za-zorganizowanagrupe-przestepcza.html $\rangle$, visited 4 October 2021.

${ }^{11} \mathrm{G}$. de Búrca and J. Morijn, 'Repression of Freedom of Expression in Poland: Renewing support for Wojciech Sadurski', Verfassungsblog, 3 June 2020, 〈https://verfassungsblog.de/repression-offreedom-of-expression-in-poland-renewing-support-for-wojciech-sadurski/ $\rangle$, visited 4 October 2021.

${ }^{12}$ See G. de Búrca and J. Morijn, 'Open Letter in Support of Professor Wojciech Sadurski', Verfassungsblog, 6 May 2019, 〈https://verfassungsblog.de/open-letter-in-support-of-professorwojciech-sadurski/ $/$, visited 4 October 2021.

${ }^{13}$ For an overview of various ways in which academics and political actors expressed their support for Sadurski see J. Morijn and B. Grabowska-Moroz, 'Supporting Wojciech Sadurski in a Warsaw Courtroom’, Verfassungsblog, 28 November 2019, 〈https://verfassungsblog.de/supporting-wojciechsadurski-in-a-warsaw-courtroom/ $\rangle$, visited 4 October 2021.

${ }^{14}$ See De Búrca and Morijn, supra n. 11. 
Sadurski, '\#WithWoj', clearly saw their action as meaningful - another sign of academics' awareness of their power in the public sphere.

There are other forms of power than the public one, however, and constitutional scholars are not immune to them either. Money or, more generally, economic power - long ignored as a topic of constitutional (or even legal) theory ${ }^{15}$ - is one of them. It is in the nature of the discipline, and also due to its historical development, that 'many law professors, teachers and researchers are more familiar with legal professionals than with their colleagues from other faculties. In fact, many academic lawyers are also practising lawyers, and true academics are a rare breed in law schools', ${ }^{16}$ a historian of law once observed.

In 2019 Dimitry Kochenov's activities outside his university became a matter of public controversy and investigation in the Netherlands. ${ }^{17}$ Kochenov became involved in a business concerning people who are wealthy enough to buy citizenship. Such citizenship must be available for sale and at the same time of sufficient 'quality' to be attractive to the investor. This involvement was consistent with Kochenov numerous academic ${ }^{18}$ (and less academic) ${ }^{19}$ publications, where Kochenov argues that this business is the way to promote justice and do away with the 'hypocrisy of citizenship'.

We know that academics in other fields - even where dealing with nature and its laws, which humans can only discover rather than make - can get involved in political controversies or get too close to those who pay for their research. ${ }^{20}$ Think

${ }^{15}$ See J. Britton Purdy et al., 'Building a Law-and-Political-Economy Framework: Beyond the Twentieth-Century Synthesis', 129 Yale Law Journal (2020) p. 1784 or G. Sitaraman, 'The Puzzling Absence of Economic Power in Constitutional Theory', 101 Cornell Law Review (2016) p. 1445. Both articles have been written in the specific context of the United States, however many of their arguments also apply to Europe.

${ }^{16} \mathrm{~N}$. Hammerstein, with the collaboration of D. Heirbaut [the author of the text quoted here], 'Social Sciences, History and Law', in W. Rüegg (ed), Universities Since 1945. A History of the University in Europe, vol. IV (Cambridge University Press 2011) p. 371 at p. 414, emphasis added in order to highlight this point: many people simply do not think that lawyers employed by universities are 'true academics'.

${ }^{17}$ For a short report in English, with references to relevant documents, see 'Investigation into additional activities of UG professor of European Constitutional Law and Citizenship concluded' 8 June 2020, 〈https://www.rug.nl/about-ug/latest-news/news/archief2020/nieuwsberichten/ uitkomst-onderzoek-nevenwerkzaamheden-rug-hoogleraar-europees-constitutioneel-recht-enburgersch $\rangle$, visited 4 October 2021.

${ }^{18}$ See e.g. D. Kochenov, Citizenship (MIT Press 2019).

${ }^{19}$ See e.g. D. Kochenov, 'Citizenship is a hypocritical scam that preserves and reinforces global inequality', NBC News Thought Experiment, 26 February 2020, 〈https://www.nbcnews.com/think/ opinion/citizenship-hypocritical-scam-preserves-reinforces-global-inequality-ncna1 143431〉, visited 4 October 2021.

${ }^{20}$ See e.g. S. Jasanoff, Science and Public Reason (Routledge 2012), a collection of essays that consider this issue from various perspectives. 
of climate change or genetics. However, we also know that the kind of politics constitutional scholars deal with is different. Constitutional law is not only close to public power; it constitutes it and structures the way in which politics is done. ${ }^{21}$ Public pronouncements by constitutional scholars, or some of them at least, are therefore acts of public power (understood broadly), given the 'imposed normativity of all legal scholarship' mentioned above. ${ }^{22}$

This has consequences not only for what constitutional scholars do, but also for how they do it. It brings questions about their responsibility and - which is very often forgotten - the limitations on their freedoms. The remainder of this article deals with this issue from two perspectives: it first seeks to identify the kind of authority constitutional scholars resort to when speaking academically. It then looks at how the protection of scientific authority and even academic freedom can affect their freedom of expression. In the final section I also consider the power of the academic collective.

\section{CONSTITUTIONAL SCHOLARSHIP AS POWER}

What gives constitutional scholars their power - and authority?

The precise answer differs from one country to the next. ${ }^{23}$ Since the time of the Roman Empire, legal science has occupied an important place in legal systems on the European continent. ${ }^{24}$ With the emergence of the modern state and its public law in the seventeenth century, publicists, and later constitutional scholars, became important for the legitimation of the state and its legal regime. ${ }^{25}$ Jurisprudence, was 'the leading science for the internal structure of the modern

${ }^{21}$ Supra n. 4. Dieter Grimm posits five characteristics that distinguish constitutionalism from a mere 'legalisation of public power': see 'The Achievement of Constitutionalism and its Prospects in a Changed World', in P. Dobner and M. Loughlin (eds.), The Twilight of Constitutionalism? (Oxford University Press 2010) p. 3 at p. 9.

${ }^{22}$ Tuori, supra n. 4.

${ }^{23}$ See W. Twining et al., 'The Role of Academics in the Legal System', in M. Tushnet and P. Cane (eds.), The Oxford Handbook of Legal Studies (Oxford University Press 2005) p. 920.

${ }^{24}$ See P. Jestaz and C. Jamin, La doctrine (Dalloz 2004).

${ }^{25}$ See e.g. W. Schmidt-Biggemann, 'New structures of knowledge', in H. de Ridder-Symoens (ed.), Universities in Early Modern Europe (1500-1800). A History of the University in Europe, vol. II (Cambridge University Press 2003) p. 489 at p. 515. For Germany see J.E. Khusal Murkens, From Empire to Union: Conceptions of German Constitutional Law since 1871 (Oxford University Press 2013) Ch. 1; for France, G. Sacriste, La République des constitutionnalistes: Professeurs de droit et légitimation de l'État en France (1870-1914) (Presses de Sciences Po 2011). 
state, especially in the German Empire, the Netherlands, Italy and Scotland'. ${ }^{26}$ At the same time, however, legal scholars have always claimed that law is autonomous from politics. They have sought independence from politicians and other power holders. The most effective tool to achieve this has been to present legal (and constitutional) scholarship as a form of science. ${ }^{27}$

Science has claimed autonomy from the state and Church since at least the scientific revolution of the seventeenth century. ${ }^{28}$ One of the places in which to search for 'the objective pursuit of truth', as the longstanding idea of science has had it, ${ }^{29}$ was university. ${ }^{30}$ Legal science, which has been a part of European universities from their very beginning, ${ }^{31}$ has therefore always possessed 'dual citizenship'. It has formed part of legal and political practice, and at the same time partook in scientific reflection and advancement of knowledge - the core of the academic enterprise. ${ }^{32}$

The emancipation of science from state and religious authorities in the seventeenth century, however, brought new challenges to lawyers operating within universities. Immanuel Kant's argument for the superiority of the faculty of philosophy over the faculties of theology, law and medicine represents the challenge rather well. In Kant's view, the latter three faculties were 'places in which the future servants of the Church and the state were educated ${ }^{33}$ and therefore could

\footnotetext{
${ }^{26}$ Schmidt-Biggemann, supra n. 25, p. 515. By 'jurisprudence', Schmidt-Biggemann refers to the science of public law, which was also crucial for establishing the state's claim of sovereignty over the churches and turned religion into a private matter: ibid, p. 516 .

${ }^{27}$ The alliance between law and science was not only pragmatic. At the time, numerous thinkers believed that science could bring justice to the legal system. See R. Berkowitz, The Gift of Science: Leibniz and the Modern Legal Tradition (Harvard University Press 2005).

${ }^{28}$ See R.P. Crease, The Workshop and the World: What Ten Thinkers Can Teach Us About Science and Authority (W.W. Norton Company 2019).

${ }^{29} \mathrm{E}$. Kale-Lostuvali, 'Two Sociologies of Science in Search of Truth: Bourdieu versus Latour', 30 Social Epistemology (2016) p. 273 at p. 273.

${ }^{30}$ See R. Porter, 'The Scientific Revolution and Universities', in de Ridder-Symoens, supra n. 25, p. 531.

${ }^{31}$ The very first lecture in the history of European universities was offered in law, according to the mythology of the founding of Bologna University: see W. Rüegg, 'Themes', in H. de RidderSymoens (ed.), Universities in the Middle Ages. A History of the University in Europe, vol. I (Cambridge University Press 1992) p. 3 at p. 5.

${ }^{32}$ Supra n. 2.

${ }^{33} \mathrm{~A}$. Briggs, 'History and the Social Sciences', in W. Rüegg (ed.), Universities in the Nineteenth and Early Twentieth Centuries (1800-1945). A History of the University in Europe, vol. III (Cambridge University Press 2004) p. 393 at p. 453, referring to Immanuel Kant's Streit der Fakultaten (1798).
} 
not be deemed free. 'The philosophy faculty, by the nature of their subject, the pursuit of knowledge for its own sake, should take the highest rank in terms of academic self-determination and freedom'. ${ }^{34}$

It was emancipation from the state and Church that endowed philosophy (which in Kant's times comprised history and natural sciences as we understand them today) with its own superior authority, determined by its own criteria of reason, later called the 'scientific method'. As the historian Wilhelm SchmidtBiggemann observed,

arguing historically and pragmatically solely for the benefit of the state and its service, the jurists became incapable of dealing philosophically with the question of its legitimacy. The price jurisprudence [that is, the science of public law] paid for its political advance was a loss of critical competence. ${ }^{35}$

Legal science did not have critical methods that would be considered sufficient to establish 'objective truth', pursued by 'true' scientists. At the same time, it is probably (also) due to their social prestige and closeness to power that they were never expelled from the university. ${ }^{36}$

The problem of the absence of a 'scientific method' in legal scholarship relates to another issue legal scholars have been facing ever since the rise of sciences: the danger of 'colonisation' of law by other scientific disciplines, especially the social sciences (political science and economics in particular). ${ }^{37}$ If political scientists can better predict the outcome of cases before the Supreme Court than constitutional

\footnotetext{
${ }^{34}$ Ibid., emphasis added. For a critique of this argument about philosophy by Kant see J. Butler, 'Critique, Dissent, Disciplinarity', 35 Critical Inquiry (2009) p. 773 at p. 782. For a brief reply in the spirit of the approach to academic freedom that I follow here see S. Fish, 'Academic Freedom and the Boycott of Israeli Universities', in A. Bilgrami and J.R. Cole (eds.), Who's Afraid of Academic Freedom? (Columbia University Press 2015) p. 275 at p. 291. Butler's reply can be found in the same volume, as 'Exercising Rights: Academic Freedom and Boycott Politics' p. 293.

${ }^{35}$ Schmidt-Biggemann, supra n. 25, p. 515.

${ }^{36}$ The United States context was markedly different: law schools were long considered professional schools, whose aim was to prepare their students for legal practice, not to practise anything like 'science'. It was only in the course of the nineteenth century that law professors gained the reputation of academics (scientists), emulating the 'German model' of university and professorship. See M. Reiman, 'A Career in Itself: The German Professoriate as a Model for American Legal Academia', in M. Reiman (ed.), In The Reception of Continental Ideas in the World Common Law, 1820-1920 (Duncker \& Humblot 1993) p. 165.

${ }^{37}$ See J.M. Balkin, 'Interdisciplinarity as Colonization', 53 Washington and Lee Law Review (1996) p. 949.
} 
scholars, why do we need the latter at the university? ${ }^{38}$ And if economic efficiency is what law is about, should not all lawyers study economics rather than law? ${ }^{39}$

The answer I provide here may appear old-fashioned, but I hope it may persuade at least some. Doctrinal legal scholars actually do something different than other scientists dealing with law and legal institutions (such as political scientists or sociologists studying courts). Given the legal doctrine's dual citizenship in law and science, ${ }^{40}$ their contributions are accepted by legal (and political) practice as contributions to law, not about law. They are 'engaged in continuously elaborating doctrinal theories in order to improve their responsiveness to the legal problems of a rapidly changing society. ${ }^{41}$ This does not, of course, mean that legal science should be blind to the insights of other disciplines; 'it only creates a filter these insights must traverse before they can find their way into the legal discourse'. ${ }^{42}$ University, again, is the best place to achieve this, especially one which recognises the need for both kinds of scholarship - 'internal' doctrinal and 'external' scientific.

\section{THE CRISIS OF SCIENTIFIC AUTHORITY}

However, borrowing authority from the 'true science' can help legal scholars to protect their independence from various forms of power only to a certain point. The conception of scientific authority, which presupposed that scientific truth could be established objectively, and independent of 'external factors', including economy and politics, has been contested since Thomas Kuhn published The Structure of Scientific Revolutions in 1962. The debate which was originally internal to the academic world broke free from university walls when the power of science (and experts) was realised by the society. 'Science wars' ensued and have never

\footnotetext{
${ }^{38}$ This could be the question one might ask after the publication of T.W. Ruger et al., 'The Supreme Court Forecasting Project: Legal and Political Science Approaches to Predicting Supreme Court Decisionmaking', 104 Columbia Law Review (2004) p. 1150. Political scientists correctly predicted $75 \%$ of cases, whereas constitutional scholars only managed $59 \%$. There are now computer and big-data based instruments that may be even more successful: see O. Roeder, 'Why The Best Supreme Court Predictor In The World Is Some Random Guy In Queens', abcNews FiveThirtyEight, 17 November 2014, 〈https://fivethirtyeight.com/features/why-the-bestsupreme-court-predictor-in-the-world-is-some-random-guy-in-queens/ $\rangle$ visited 4 October 2021.

${ }^{39}$ For an incisive account of the coalition between conservative legal academics and neoclassical economists, resulting in the Law \& Economics movement see J.R. Hackney Jr., Under Cover of Science: American Legal-economic Theory and the Quest for Objectivity (Duke University Press 2007).

${ }^{40}$ See text at supra n. 32.

${ }^{41}$ Tuori, supra n. 4, p. 23.

${ }^{42}$ Ibid., p. 22.
} 
ended since. ${ }^{43}$ Hand in hand with this came the politicisation of the universities, further reinforced by student revolts both in Europe and the United States in 1968 and in the 1970s.

Universities (and colleges) in the United States especially have a rich history of struggles concerning academic freedom and the autonomy of the university, ${ }^{44}$ from the McCarthy era in the $1950 \mathrm{~s}^{45}$ to the more recent 'crisis of free speech on campus', related to the boycotting of some professors or even entire universities (from Israel), creating 'safe spaces' for debate, and, most recently, 'cancelling culture, ${ }^{46}$ Besides fearing governmental interference and the intrusion by public power, most top American universities are private and have to resist pressure from their sponsors and boards of trustees - the power of money.

How could academics (and universities) protect themselves from external pressures? One way would be to show that free scientific inquiry and academic freedom supports other things valued by society: freedom, democracy or civic virtues, or even its wealth or the 'gross national product'. ${ }^{47}$ This, however, protects academia only to the extent to which it serves such external values and interests. It seems to be the prevailing approach now, despite the fact that universities (and researchers in certain fields, particularly in arts and humanities) find it hard to justify their existence in such instrumental terms.

An alternative way is to say, along with Kant, that the pursuit of knowledge is worthy for its own sake, and to delineate the scope of academic freedom and the authority of science around this axiom. This is the approach defended by Stanley Fish and it is the one adhered to here as well. The strength (and at the same time the weakness) of Fish's approach is that it relies heavily on academics' own faithful adherence to it.

If members of the academy wish to continue doing what they have been trained to do, it is up to them to monitor the conditions - the list of professional dos and don'ts - that ensure the health of their practice. That practice is not underwritten by any theory of truth or justice and it will not survive an interrogation that demands an independent corroboration of its cogency. It is underwritten only by its own protocols, and if they are flouted or actively rejected, the activity they

\footnotetext{
${ }^{43}$ See J.R. Brown, Who Rules? An Opinionated Guide to the Wars (Harvard University Press 2001).

${ }^{44}$ See J. Wallach Scott, Knowledge, Power, and Academic Freedom (Columbia University Press

${ }^{45}$ See M. Heins, Priests of Our Democracy: The Supreme Court, Academic Freedom, and the AntiCommunist Purge (New York University Press 2013).

${ }^{46}$ See T. Slater (ed.), Unsafe Space: The Crisis of Free Speech on Campus (Palgrave McMillan 2016).

${ }^{47}$ For an overview of such arguments see S. Fish, Versions of Academic Freedom: From Professionalism to Revolution (University of Chicago Press 2014) Ch. 1.
} 2019). 
make possible will disappear. The narrowly professional definition of academic freedom is not merely a rival account of the academy. It is the academy. ${ }^{48}$

The reason why I think Fish's conception of academic freedom is superior to the former, which relies on values outside academia, will become clear in the following part of this article. It deals with the relationship between academic freedom and freedom of expression, which often gets confused in the debates concerning academics' encounters with power.

\section{CONSTITUTIONAL SCHOLARSHIP AND FREEDOM}

In cases that have appeared before the European Court of Human Rights, the two freedoms (academic freedom and freedom of expression) have always coincided. This is most likely because academic freedom as such does not enjoy separate protection in the European Convention on Human Rights. ${ }^{49}$ As a result, the jurisprudence of the European Court of Human Rights lacks a coherent doctrine of academic freedom. As noted in the concurring opinion of judges Sajó, Vučinič and Küris in Mustafa Erdoğan and Others v Turkey delivered in 2014,

[t]he level of protection granted to academic freedom, especially in its 'extramural' manifestation, cannot be explained fully (and consequently, in a convincing and transparent way) within the four corners of the assumptions that underlie the Court's case-law concerning freedom of expression. At least as matters currently stand, these assumptions remain at the level of intuitions. The meaning, rationale and scope of academic freedom are not obvious, as the legal concept of that freedom is not settled..$^{50}$

The applicants were a professor of constitutional law, the editor of a review characterised by the European Court of Human Rights as 'a quasi-academic quarterly as opposed to a popular newspaper, ${ }^{51}$ and the publishing company. They were sued by some judges of the Constitutional Court of Turkey for the

${ }^{48}$ Fish, supra n. 34, p. 292.

${ }^{49}$ This is similar to the United States. On the other hand, the EU Charter of Fundamental Rights provides, in Art. 13, titled 'Freedom of the Arts and Sciences', the following: 'The arts and scientific research shall be free of constraint. Academic freedom shall be respected'. Many European states also guarantee academic freedom as a separate right: see K.D. Beiter et al., 'Academic Freedom and Its Protection in the Law of European States: Measuring an International Human Right', 3 European Journal of Comparative Law and Governance (2016) p. 254.

${ }^{50}$ ECtHR (Second Section) 27 May 2014, Nos. 346/04 and 39779/04, Mustafa Erdoğan and Others v Turkey, ECLI:CE:ECHR:2014:0527JUD000034604, concurring opinion $₫ 4$.

${ }^{51}$ Judgment in Mustafa Erdoğan and Others v Turkey, supra n. 50, $\$ 45$. 
professor's commentary on a decision which dissolved a political party. ${ }^{52}$ The commentary argued that the decision was 'clearly contrary to the law and ha[d] no factual or legal basis ${ }^{53}$ It also said that the professional capabilities of most of the court members are insufficient for the job'. ${ }^{54}$ The judges of the Constitutional Court successfully claimed compensation for such statements, deemed defamatory by civil courts in Turkey. The applicants in the Strasbourg Court argued that this violated their freedom of expression, granted by Article 10 of the ECHR.

The European Court of Human Rights agreed with the applicants and did not take up the question of academic freedom in much detail. The judges writing the concurring opinion wanted to go further, however, and to provide criteria on the application of academic freedom in such cases: to formulate a doctrine concerning freedom of expression as it relates to academic freedom. ${ }^{55}$ So far, the concurring opinion remains the most comprehensive statement on the matter from Strasbourg.

The opinion starts by observing that 'it would make little sense to attempt to justify the specific instance of "extramural" academic speech by a general reference to "the needs of a democratic society", the typical justification accepted for freedom of expression in the Court's case-law". ${ }^{56}$ Freedom of expression is believed to contribute to democracy, in addition to the 'individual's self-fulfilment ${ }^{\text {' }}{ }^{57}$

The concurring opinion considers that the rationale for freedom of academic expression is 'the need to communicate ideas, which is protected for the sake of the advancement of learning, knowledge and science. ${ }^{58}$ It would, therefore, seem that it

\footnotetext{
${ }^{52}$ See judgment in Mustafa Erdoğan and Others v Turkey, supra n. 50, $\$$ 6, where the ECtHR summarises the context of the national judgment.

${ }^{53}$ Ibid.

${ }^{54}$ Ibid.

${ }^{55}$ Mustafa Erdoğan and Others v Turkey, supra n. 50, concurring opinion $\$ 2$. As they note, there are other dimensions of academic freedom beyond this question, which they left unexplored. On this wider understanding of academic freedom in the European context see J. Vrielink et al. and the LERU Working Group on Human Rights, 'Academic Freedom as a Fundamental Right', LERU Advice Paper No. 6, December 2010, 〈https://www.leru.org/publications/academic-freedom-as-afundamental-right $\rangle$, visited 4 October 2021.

${ }^{56}$ Mustafa Erdoğan and Others v Turkey, supra n. 50, concurring opinion $\$ 5$.

${ }^{57}$ ECtHR (Plenary) 8 July 1986, No. 9815/82, Lingens v Austria, ECLI:CE: ECHR:1986:0708JUD000981582, $\$$ 41. Unlike in the United States, 'the search for truth' and the related 'marketplace of ideas' metaphor does not provide an independent justification for the protection of freedom of expression in the ECtHR's jurisprudence, despite its occasional occurrence in individual opinions by some judges (who like to refer to the US constitutional doctrine). For a critique of the view that freedom of expression may be justified in this way, see F. Schauer, 'Free Speech, the Search for Truth, and the Problem of Collective Knowledge', 70 Southern Methodist University Law Review (2017) p. 231.

${ }^{58}$ Mustafa Erdoğan and Others v Turkey, supra n. 50, concurring opinion, $₫ 5$, emphasis added.
} 
recognises the value of academia as self-sufficient, similar to Fish's suggestion. It adds, however:

There is no Chinese wall between science and a democratic society. On the contrary, there can be no democratic society without free science and free scholars. This interrelationship is particularly strong in the context of social sciences and law, where scholarly discourse informs public discourse on public matters including those directly related to government and politics. ${ }^{59}$

The concurring opinion therefore only takes a detour to mention the pursuit of knowledge, in order to arrive at a destination common to freedom of expression. The importance of the 'academic element' in the expression by the academic would consist, according to the concurring opinion, 'in finding whether a particular "speech" which otherwise would constitute an unlawful infringement of personal rights is protected under Article 10, ${ }^{60}$ Speech by academics would therefore enjoy greater protection: 'the presence or absence of an "academic element" in an impugned comment or utterance may be decisive in finding whether a particular "speech" which otherwise would constitute an unlawful infringement of personal rights is protected under Article 10' ${ }^{61}$ In determining whether the speech has this academic element,

it is necessary to establish: (a) whether the person making the speech can be considered an academic; (b) whether that person's public comments or utterances fall within the sphere of his or her research; and (c) whether that person's statements amount to conclusions or opinions based on his or her professional expertise and competence. ... Where and how (inter alia, in what form of publication or to what audience) the 'speech' was given or was otherwise made public is a secondary, auxiliary and often not decisive factor. ${ }^{62}$

${ }^{59}$ Ibid., $₫ 6$. The concurring opinion even refers to 'Recommendation No. R(2000)12 of the Committee of Ministers to member States on the social sciences and the challenge of transition, [which] emphasised that "the social sciences play a strategic role in guaranteeing an informed public and in building a society based on democracy" and that "all democracies have a growing need for the social sciences for their economic and social development, to help their institutions to understand and to solve societal problems, to increase the confidence of their citizens in democracy and to enhance the vigour of the democratic process itself, encompassing electoral politics, government, and civil society"'. This would subject completely the protection of academic freedom to the needs of the political system in question.

${ }^{60}$ Ibid., $\$ 6$.

${ }^{61}$ Ibid.

${ }^{62} \mathrm{Ibid}$. 
To me, such protection looks slightly over-extensive, concerning the form of publication, which according to the concurring opinion should not matter. In my view we need to be more discriminating, especially regarding 'extra-mural' speeches and other forms of communication. Blogging professors seem to be a matter of the past - 'tweeting professors' is the order of our days, and we may only wait until professors cease to communicate in words altogether, and go to Instagram, as some venerable judicial institutions have done already. ${ }^{63}$ In my view, however, not everything the professor says (or communicates) becomes 'academic' - professors are not King Midas. Tweets limited to 160 characters, whose point is usually not to make an argument but to attract attention (and get followers) can only rarely be of such nature, unless we want to relax dramatically the standards of what counts as 'academic argument ${ }^{64}$ Contrary to what the concurring opinion states, the medium should matter in determining whether the speech contains an academic element or not. Tweets may be important for the public debate (and as such protected by the freedom of speech), but only rarely pursue knowledge, which is the point of academic freedom, as argued above.

\section{ACADEMIC FREEDOM - AND RESPONSIBILITY}

There are more dimensions to academic freedom than an individual academic's right to free speech. An advisory paper, published by LERU, the League of European Research Universities, ${ }^{65}$ identifies three dimensions of academic freedom. Besides ' $[f]$ ar-reaching individual rights to expressive freedoms for members of the academic community (both staff and students) mainly as free enquirers', ${ }^{66}$ the other two concern 'collective or institutional autonomy for the academy' and the obligation for the public authorities to protect them. ${ }^{67}$ In the advisory paper's opinion, these three dimensions:

are not mutually exclusive, but on the contrary they mutually reinforce one another. In case of conflict between the individual and the institutional rights, a careful balancing of rights and interests may be needed, in which special consideration is to be given to the former aspects. ${ }^{68}$

${ }^{63}$ See S. Steininger, 'Wipe up for the German Federal Constitutional Court on Instagram: Judicial Storytelling in the Era of Social Media', Verfassungsblog, 19 August 2021, 〈https:// verfassungsblog.de/the-gfcc-on-instagram/ $\rangle$, visited 4 October 2021.

${ }^{64}$ The (over) use of social media by some academics is an issue beyond the scope of this article. Just to note that some people confuse doing academic work for promoting it (or themselves).

${ }^{65}$ It comprises 23 institutions based in 12 different countries: see /https://www.leru.org/ members $\rangle$, visited 4 October 2021.

${ }^{66}$ See Vrielink et al., supra n. 55, p. 3.

${ }^{67}$ Ibid.

${ }^{68} \mathrm{Ibid}$. 
This view, giving primacy (or 'special consideration') to individual over institutional rights, may be contested. Indeed, it is hard to find something specific about academic enterprise that should give individual academics some special privileges over ordinary citizens, who enjoy protection from other constitutional provisions. ${ }^{69}$ To say that extramural - i.e. outside academic context - speech by academics deserve some greater protection in a democracy, as the Mustafa Erdoğan concurrent opinion holds, sounds patently undemocratic. Democracy is not about searching for truth, but living free in common, as equals. In a democracy, unlike in academia, every voice counts the same (at least legally/formally). In science, it is different. Academic achievement and distinction bring stronger voice, and authority.

Privileging the search for truth thus makes sense only in its own proper context - i.e. within academia. ${ }^{70}$ This is there where academics deserve additional protections, which give them privileges that ordinary citizens do not have (to say things that may otherwise be harmful or defamatory, or to be freer from their employer's directions than other employees are).

The flip side of these privileges is the imposition of constraints on academics that other citizens may not have. It is clear that academics cannot say whatever they want, if they want to enjoy the protection of academic freedom. As 'ordinary citizens' they can speak up as much as they deem necessary - but as I explain below, they should always consider the implications of their free speech for the academic freedom of their colleagues. When teaching, they must remain as nonpartisan as possible and not advocate what they believe to be 'the right thing. ${ }^{71}$ As Stanley Fish put it:

$[\mathrm{O}]$ ne exercises academic freedom when determining for oneself (within the limits prescribed by departmental regulations and graduation requirements) what texts, assignments, and exam questions will best serve an academic purpose; one violates academic freedom by deciding to set aside academic purposes for others thought to be more noble or urgent.

${ }^{69}$ For a strong argument in favour of institutional academic freedom (made in the US context) see F. Schauer, 'Is There A Right to Academic Freedom?', 77 University of Colorado Law Review (2006) p. 907.

${ }^{70}$ For a contrary view see K.E. Whittington, 'Academic Freedom and the Scope of Protections for Extramural Speech', 〈https://ssrn.com/abstract=3294421〉, visited 4 October 2021.

${ }^{71}$ Granted, this is markedly more difficult when teaching constitutional law than when teaching sixteenth-century English literature. However, there are boundaries too. 
Of course one is free to prefer other purposes to the purposes appropriate to the academy, but one is not free to employ the academy's machinery and resources in the service of those other purposes. ${ }^{72}$

It is therefore completely appropriate for universities to maintain control over their academics' ancillary activities, as these may compromise academic freedom in its institutional dimension. It is not at all clear to me why the individual dimension of academic freedom should have an automatic precedence over the collective/institutional one, as LERU's advice paper claims. A speech or any other activity deserves the protection of academic freedom only as long as it aims at the academy's core purpose, which is the pursuit of knowledge. And an institution may be better placed than an individual to make the judgment of whether that is the case, especially if pecuniary or other private interests on the side of the individual academic are at stake. ${ }^{73}$ This is of course a delicate balance, given that universities themselves are dependent on both public and private funding and may want to supress research (and communication by academics) that may unsettle their donors. If, however, we want to preserve the definition of what the pursuit of knowledge is (and is not) in the hands of academics, I believe that there is a good case to trust them instead of individuals and their legalised rights adjudicated by courts in the last instance.

The peculiar problem with legal academics, of course, is that in many places it is completely normal also to have a business or be a partner in a law firm. This should not, however, mean that we just let all this go: remember, academic enterprise is underwritten only by its own protocols, and if they are flouted or actively rejected, the activity they make possible will disappear. ${ }^{74}$ If we want to keep respect of our colleagues at other faculties - and truly protect academic freedom - we should be less relaxed about what seems to be common in many places.

It is also important to be clear what is at stake: academic integrity and trust in scientific expertise. It is not universities' reputation, which may be the thing that matters most in today's world of various rankings. ${ }^{75}$ The latter concern reflects the widespread monetisation of academic enterprise, ranging from an ever-growing need to bring in 'external' money (and pursue the knowledge recognised as

\footnotetext{
${ }^{72}$ S. Fish, Save the World on Your Own Time (Oxford University Press 2008) p. 81, emphasis added.

${ }^{73}$ It is also important to note that most universities and research institutions adopt codes of conduct regarding research integrity - and academics' ancillary activities.

${ }^{74}$ See text quoted at supra n. 48, emphasis added. In that light I think it is important to have this debate, so that it is known that at least some members of academia find such practice to be contrary to academic freedom.

${ }^{75}$ This is a topic that cannot be explored in full here. For an introduction see M. Thornton, Privatising the Public University: The Case of Law (Routledge 2012).
} 
valuable by those who provide the money, rather than knowledge valued - and validated - by academics and their own protocols), to the big 'speaker's fees' for prominent academics who, instead of doing philosophy and talking to their colleagues at less endowed universities, turn to philosophising in public - telling it what it wants to hear (and pays for).

Academics engaging in private business can violate academic freedom in at least two respects, one obvious and the other less so. First, they may 'employ the academy's machinery and resources in the service of [their own] purposes, ${ }^{76}$ which - if we apply Stanley Fish's criteria - actually violates academic freedom understood as the enterprise maintained by (and for) all academics. It is therefore contrary to academic freedom to use one's research assistants to support work that is intended for their professor's non-academic business (private or public).

Second, it is problematic if academics do not mention their involvement in private business (or public advocacy) when writing op-eds or academic articles that support their non-academic goals. In my view such people profit from their colleagues' collective achievement, which consists in (a very fragile, to be sure) public trust in their objectivity and impartiality, and repurpose that asset to their own non-academic ends. It makes a big difference, when a professor of constitutional law argues that citizenship should be for sale, if at the same time that professor is involved in the business of assisting wealthy people and governments on the same topic.

The duty to disclose potential conflicts of interest has become a norm in most sciences and should be the primary norm for legal scholars too. To borrow from the analogy that Wojciech Sadurski used to defend his involvement in public affairs: would anybody listen to 'an epidemiologist who actively participates in public actions to counter the pandemic', ${ }^{77}$ if they knew that the same person had stakes in the pharmaceutical business with vaccinations and protective equipment? Trust lies at the heart of the production of knowledge and that is why academics have adopted research ethics codes to protect it. ${ }^{78}$

Preferring the institutional over the individual dimension may be good (or even necessary) for the sake of academic freedom itself. Its point, among other things, is to keep the judgment on what passes as 'academic' for academia itself. Judicial protection may be necessary to oversee the regularity of process within academia, but substantive determination should not be made by judges - no matter how erudite they may be.

\footnotetext{
${ }^{76}$ See the quotation at supra n. 72.

${ }^{77}$ Supra n. 9.

${ }^{78} \mathrm{On}$ the role of trust in this respect see J. Hardwig, 'The Role of Trust in Knowledge', 88 Journal of Philosophy (1991) p. 693.
} 
This may have some implications for how we perceive constitutional scholars active in public (and political) battles of the day. 'The cover of science', ${ }^{79}$ used by legal scholars to protect their autonomy, has become rather porous with the rise of 'science wars' and the ensuing lack of social trust in science and experts. Again, the experience of the United States can be instructive.

In the early 2000s the US Congress and the legislatures of one third of all states considered adopting the 'Academic Bill of Rights'. ${ }^{80}$ The Bill sought to 'restore the balance' tilted too much (in view of those who supported it) in favour of liberals and left-wing professors in general. It resulted from efforts of David Horowitz, the author of the book titled The Professors: 101 Most Dangerous Academics in America. ${ }^{81}$ The book announces on its inside flap: 'Coming to a Campus Near You: Terrorists, racists, and communists - you know them as The Professors'.

One reaction can be shock (and perhaps sympathy for those who appeared on such a 'kill-list'). How horrible it is to accuse academics of dirty politics (or even of supporting terrorism). But then we may think a little longer and imagine: what if such Bills and other efforts to control 'ideological balance' at universities result from (some) American professors' passionate engagement outside academia, where they do not act as knowledge-seekers, but rather as actors exercising their power in favour of partisan politics? It is certainly legal for them to do this (protected by the freedom of expression, not academic freedom); however, it may harm those very same professors and all their colleagues in academia. If constitutional law professors engage in politics, can they be trusted not to do the same within university walls? Why not turn faculties of law into another political arena? ${ }^{82}$

One may think that defending the rule of law and other liberal values can never be seen as 'partisan' - especially if one believes that liberalism is more neutral (or less ideological) than socialism (or conservatism) ${ }^{83}$ But if ideology means, among other things, concealing the structures of domination, liberalism is no less ideological than the other two. And its actual force lies in the fact that it is still not perceived as such. So it may help liberal democracy if extramural speeches at least seek to keep an appearance of neutrality and try to see beyond ideology. ${ }^{84}$

\footnotetext{
${ }^{79}$ Supra n. 39.

${ }^{80}$ On the Bill and its context see R.M. O'Neil, 'Bias, "Balance," and Beyond: New Threats to Academic Freedom', 77 University of Colorado Law Review (2006) p. 985.

${ }^{81}$ Regnery Publishing 2004.

${ }^{82}$ Which is something that has happened already, according to some, although the politics is of a different kind to that which we imagine as 'partisan', or 'properly political': see S.M. Teles, The Rise of the Conservative Legal Movement: The Battle for Control of the Law (Princeton University Press 2008).

${ }^{83}$ See M. Warren, 'Liberal Constitutionalism as Ideology: Marx and Habermas', 17 Political Theory (1989) p. 511.

${ }^{84}$ In fact, we do not need to travel across the Atlantic to find important lessons about the importance of keeping legal science 'pure'. Writing about legal science in the late Habsburg monarchy,
} 
The judges of the European Court of Human Rights were right in their concurring opinion in the Mustafa Erdoğan case: there are no Chinese walls between academia and society. This, however, works both ways: it also means that there is no protection of academia from society. The point of the 'narrow' understanding of academic enterprise is precisely this. Being aware of the contingency of all external justifications, it turns to itself to remain what it really is: a place where knowledge can be pursued without external interference. For some people this is not enough. But in that case, some of them must decide what they prefer and make a choice about what is really important to them.

\section{Constitutional SCHOLARSHIP's COLLECTIVE POWER}

Protecting academic freedom as a collective enterprise should not, however, mean that we ignore the power of the academic collective. This is the last issue I would like to address in this article.

Increasingly, constitutional scholars publish statements where they argue for a particular solution to a public controversy, referring to their academic expertise as a basis of the opinion. Verfassungsblog has become a popular place for such academic campaigns, through which, to be sure, scholars can increase their 'social impact', as required today by many funders (and - increasingly - the universities who depend on them).

The letter written in support of Wojciech Sadurski stated: 'It is clear to any observer with the most elementary knowledge of EU law and the law of the European Convention on Human Rights that the three cases against Professor Sadurski will not survive the scrutiny of the Strasbourg (ECHR) or Luxembourg (EU) courts' ${ }^{85}$ The letter received hundreds of signatures by academics (many of them professors) in few days. This is highly problematic for several reasons.

First, the letter suggests that anyone who disagreed must be lacking the most elementary knowledge' of European law. However, at least the following can be said to doubt such a straightforward conclusion: the EU courts can hardly scrutinise such cases, unless they receive them through a preliminary reference made by the same Polish court that was so much distrusted by the academics. Second, and

Michael Stolleis observes: 'For a class of scholars which many were of Jewish background and thus usually opted for democracy, right of freedom, emancipation and social balance, "scholarliness" was also the suitable platform to combat the anti-Semitism that had long since become virulent in Austria and where clericalism that to some extent went hand in hand with that': M. Stolleis (T. Dunlap transl), A History of Public Law in Germany 1914-1945 (Oxford University Press 2004) p. $155-156$.

${ }^{85}$ De Búrca and Morijn, n. 12 
possibly more importantly, academic freedom in the EU is exercised in the context of a market integration project, not constitutional democracy. ${ }^{86}$ It is, therefore, not so clear that Professor Sadurski's case falls within the jurisdiction of the European Court of Justice. ${ }^{87}$ Finally, even the conclusion concerning the violation of the European Convention is not so clear. While the authors of the letter claim that 'case law makes clear that sharp criticism of politicians is covered by that protection, and that legal proceedings brought against critics even for harsh political criticism constitutes an unlawful interference with such freedom of expression' ${ }^{88}$ reading the judgment of the European Court of Human Rights in Scharsach and News Verlagsgesellschaft mbH $\mathrm{v}$ Austria (the 'case law' referred to by the letter) ${ }^{89}$ leaves a more nuanced picture: nothing in the judgment suggests that some parties cannot bring a lawsuit to protect their reputation or the rights of others. On the contrary, the Court found this to be a legitimate aim within the meaning of Article 10(2) of the Convention. ${ }^{90}$

The foregoing may be wrong, but if it is, I am sure that its wrongness doesn't stem from an absence of some elementary knowledge of European law. Tenured professors can write such things: but how about a $\mathrm{PhD}$ or postdoctoral researcher seeking a less precarious positon in academia? Campaigns like this may in fact do more harm than good to academic freedom.

Moreover, to form an expert opinion on the above matter requires time and energy. How much of that had the many signatories devoted to the issue before adding their name (often with academic title) to the many others? This may be hazardous for the public authority of constitutional scholarship, which should be exercised based on reasoned expert reflection and not emotions, moral condemnation or - worse $-\mathrm{a}$ kind of group thinking. This is a larger point, relating to the power of the academic collective and the importance of critical judgment exercised by each of us independently from others - no matter how many they are.

Public campaigns by academics are gaining popularity. After the German Federal Constitutional Court declared the European Court of Justice's ruling

${ }^{86}$ See T. Dezso Ziegler, 'Academic Freedom in the European Union: Why the Single European Market is a Bad Reference Point', MPIL Research Paper Series No. 2019-03, 〈https://ssrn.com/ abstract $=3317406\rangle$ visited 4 October 2021.

${ }^{87}$ See ECJ (Fourth Chamber) Order of 6 October 2005 in Case C-328/04 Vajnai [2005] ECR I-8577.

${ }^{88}$ G. de Búrca, J. Morijn and M. Steinbeis, 'Stand with Wojciech Sadurski: his freedom of expression is (y)ours' Verfassungsblog, 18 November 2019, 〈https://verfassungsblog.de/stand-withwojciech-sadurski-his-freedom-of-expression-is-yours/ $\rangle$, visited 4 October 2021.

${ }^{89}$ ECHR (First Section), Application No. 39394/98, judgment of 13 November 2003, ECHR 2003-XI.

${ }^{90}$ Scharsach and News Verlagsgesellschaft $m b H \mathrm{v}$ Austria, $\$ 27$. 
in Weiss ultra vires, ${ }^{91}$ a group of academics wrote a joint statement condemning the German Court and an academic theory which seeks to make sense of how constitutionalism operates in the $\mathrm{EU}$ in the following words:

We write this statement to express our shared view that the German Court's (Bundesverfassungsgericht - BVerfG) assertion that it can declare that a CJEU judgment 'has no binding force in Germany' is untenable and must be forcefully rejected. We also write to challenge those versions of scholarship on constitutional pluralism and constitutional identity that would defend the authority of the BVerfG or any national court to make such a ruling and that helped (even if unintentionally) encourage it to do so. ${ }^{92}$

Everybody who is tempted to take part in such collective exercise of academic power should be reminded of this: 'the academic task is to discover truths rather than adhere to truths already established'. ${ }^{33}$ So why not have a debate on Weiss, constitutional pluralism, or indeed, academic freedom instead of issuing collective petitions to enforce one right answer certified by as many signatures as one can get?

\footnotetext{
${ }^{91}$ BVerfG, judgment of the Second Senate of 5 May 2020, 2 BvR 859/15, paras. 1-237, 〈http:// www.bverfg.de/e/rs20200505_2bvr085915en.html $>$ visited 4 October 2021, ruling on the ECJ (Grand Chamber), judgment of 11 December 2018, Weiss and Others, C-493/17, EU: C:2018:1000.

${ }^{92}$ R.D. Kelemen et al., 'National Courts Cannot Override CJEU Judgments: A Joint Statement in Defense of the EU Legal Order', Verfassungsblog, 26 May 2020, 〈https://verfassungsblog.de/ national-courts-cannot-override-cjeu-judgments/ $\rangle$ visited 4 October 2021.

${ }^{93}$ Fish, supra n. 47, p. 50.
} 